\title{
Level of Student Cycle in Local Process (SURVEY STUdy In PHYSICAL EDUCATION STUdENT OF FKIP UNTAN PONTIANAK)
}

\author{
Viktor Simanjuntak ${ }^{1)}$, Januar Inggar Yadi ${ }^{2)}$ \\ 1) Tanjungpura University, Pontianak, Indonesia \\ E-mail: victorgsim@yahoo.co.id.com \\ 2) Tanjungpura University, Pontianak, Indonesia \\ E-mail: januaringgar@gmail.com
}

\begin{abstract}
The problem in this research is that in the lecture, there are always students who come late, even if they attend the lecture only to note their presence, in collecting the task given by the lecturer is always late from the set schedule, the lack of awareness of discipline and the sense of responsibility to carry out the order. The purpose of this research is to know the level of discipline, attitude, honesty and responsibility of physical education student FKIP UNTAN. The approach used in this research is descriptive method in the form of survey. The population is all students of Physical Education Program FKIP UNTAN odd semester of 186 people. The sample used a total sampling of 186 people.

The results are classified into three classifications that are very good at $17.2 \%$, both at $65.1 \%$ and enough at $17.7 \%$. While the total score of grouping of attitude, honesty and overall responsibility level is 25301 which is included in the good classification, indicating that student discipline in lecturing process has been running well.
\end{abstract}

Keywords: Level of Discipline; Students; Lecturing Process

\section{INTRODUCTION}

Physical education is a useful learning program both as an individual and as a member of the community, done consciously, intensively and systematically through physical activity in order to obtain the improvement of ability and skill of body, growth, intelligence and the formation of one's character.

As stated by Johar Permana Nursisto (http:/ puterirahayuu.com/ 2012/05/ discipline-html), discipline is a condition created and formed through a process, and a series of behaviors that demonstrate the values of obedience, faithfulness, loyalty, regularity and order. Meanwhile, according to Nitisemito (in Journal of Science and Technology 2008: 103) discipline can be seen from the attitude, behavior, and deeds in accordance with the rules of the organization whether written or not.

Discipline is a parameter in the determination of success, therefore a successful person is one who has the attitude of discipline, shown by coming on time in following the lecture, has the nature of hard work, to guide behavior, morals and good personality. In physical education, the role of discipline is very important because it is a demand for the continuity of life together, orderly and orderly for progress and changes in a better direction. When the process of lecturing, students are required to think scientific, have the attitude of discipline that is always indicated by the presence on time before the lecture takes place, so that in everyday life students have a culture of discipline. Discipline becomes a problem that is considered too big and complicated to be solved because the discipline is directly related to someone's personality. The cause can occur out of control and spend time disciplining someone. Based on observations and information from some students found some problems are:

a. At lecture hour it is often late to be associated with a tolerant lecture contract to be late in attendance of 10-15 minutes, the limit for absence of a maximum of 3 lectures in one semester, there are only present to get the presences without 
attending the lectures seriously. really and even make a fuss in the classroom.

b. At the time of the assignment of the lecturer such as making papers, field observations and other types of structured tasks, always too late to collect, because delay time to work, and some even do not collect.

c. Lack of awareness for discipline, a sense of responsibility for orderly conduct, and campus rules.

This research is expected to be an evaluation material for students to always raise awareness to have a disciplined attitude in order to be a good and correct example, especially when later in the day become a teacher.

\section{LITERATURE REVIEW}

\section{A. Understanding Discipline}

The word discipline comes from the Latin discipline which refers to teaching and learning. This word associates very closely with the term disciple which means to follow people learning under the supervision of a leader (Maman Rachman, 1997: 167). Discipline is basically conform to norm that always adheres to the norms that apply, obey the rules will realize an orderly situation where people who join in an organization to submit and obey the rules that have been there with pleasure (Journal of Science and Technology Sports 2008: 102)

Discipline is something that concerns one's self-control over the forms of rules. Nurdin Khan (in http: // nurdinkhan. wordpress.com/ 2012/05/30 / student-disciplinary-discipline /) distinguishes the word discipline by disciplining. Discipline is usually defined as behavior and order in accordance with rules and regulations, or behaviors derived from training, such as discipline in the classroom or discipline in a good team sports team. While the word discipline is defined as creating an orderly state and obedient to training and supervision and punish or impose fines, correct, punish for the sake of habit. According to Paul J. Meyer (in http://reypadji.wordpress.com/2011/03/21/24

kuncisukses) discipline is a must have in life, because if someone does not have a sense of discipline, that person will not have what -What.

Discipline as a form of mental attitude is absolutely necessary for the process of achieving the highest achievement. Husdarta (2011: 91) distinguishes the discipline into 2 that is selfdiscipline and pseudo-discipline. Self-discipline is an embedded discipline on the basis of deeper understanding and awareness to respect and comply with all applicable values, norms, and rules, regardless of whether or not there is oversight, sanction, punishment or reward. Pseudo discipline is a discipline implanted by coercion, for fear of punishment or sanction, for commandment without understanding and consciousness.

\section{B. Various Forms of Discipline}

Newstrom (in John May Armandi Journal of Science and Technology, 2008: 103) mentions the existence of two disciplines, namely preventive discipline, and corrective discipline. Preventive discipline is an action undertaken to encourage a person to comply with standards and regulations so that no offense occurs. Whereas corrective discipline is the action is taken to deal with violations of the rules and try to avoid further violations.

According to Soedijarto (1989: 179) the values of discipline in educational institutions that is sincere honesty, the establishment of good attitude and responsibility to make educational institutions as a socialization and learning center and dedication to the science for the development of the nation in particular and mankind in general.

Various forms of discipline other than as mentioned above, the discipline is also divided into:

1. Personal Discipline is a discipline that concerns the attitude of a person to want to obey or leave discipline. Self-discipline is essential to establish responsible behavior. An example of selfdiscipline is never too late to be present in lectures.

2. Social Discipline is a discipline related to society and is of great importance in shaping social interaction and communication in society. Social discipline aims to maintain the good name of society and its environment. Examples of behavioral social discipline are implementing siskamling (mobile security system) and consecrated work.

3. National Discipline, defined by itself as the state of a person who obeys and abides by the rules applicable to support national development (www.smkratnawartha.sch.id/index.php/2info/72d erstanding-and- kind -of-discipline).

According to H.J.S. Husdarta (2011: 102) discipline divided into three kinds of indicators, namely: the behavior of discipline in the classroom, outside the classroom, in the school environment, and at home. Meanwhile, according to Syafrudin (in nurdinkhan.wordpress.com/ 2012/05/30 / questionnaire) students divide the indicators of learning discipline into four types: obedience to study time, obedience to lesson tasks, obedience to the use of learning facilities, and obedience using time comes and goes home.

\section{Factors Affecting Discipline}

Factors that influence discipline according to Newstrom (in Journal of Science and Technology of Sports, 2008: 103) are: Commitment, is the fundamental or inclination in a person to feel active with a full sense of responsibility because without a strong commitment someone will not be disciplined in performing their duties. Knowledge, everything 
that is known and has been tested the truth about his duty then someone will be disciplined in carrying out his duties. Skill is an ability or an advantage over task. Work climate is a working atmosphere that allows to carry out the task.

One can discipline oneself because they have a certain incentive or purpose so that factors from within a person also influence the level of discipline. The formation of discipline as a patterned and regular behavior is influenced by Family Environment, School Condition, Community Condition (riedwhan.pun.bz/kedisiplinan-and-faktoryangmemp.xhtml)

Factors that may affect the culture of discipline include:

1. The person who is disciplined, ie the transition starts from someone who is mistaken for discipline and tries to be disciplined. If a person never tries to discipline, then there will be a mistake in the discipline which is an incorrect behavior.

2. Disciplined thoughts, the fact that is not conducive to make one to think must be disciplined in order to form self-belief and create discipline for the path to greatness.

3. Disciplined action, a disciplined person will always produce great results for disciplinary action (Jim Collins, 2004: 179).

\section{Problem Solving Discipline}

Jerome S. Arkaro (2005: 59) explains some disciplinary solutions for learners that is, educators can: give support and empathy to learners, show respect for learners who often disrespect themselves or others, rely on the highest expectations of behavior and knowledge of learners, be a good listener for learners and can be a person who is trusted, learners; educators are places where learners appreciate their abilities, educators are a place for learners to feel compelled to risk learning, and each class should be a safe haven for educators.

\section{E. Understanding Students}

According to W.J.S. Poerwadarminta (2003) mahasiswa have literally derived from 2 (two) words maha and siswa. maha has the meaning of a bound form, very very, very, very, very. great, while the siswa is a disciple. Simply put, mahasiswa is a great student. In RI government regulation no. 30 years 1990 students are learners registered and studying at a certain college (http://definisipengertian.com//20s/ definition - student - according to - experts /).

Agreed with that Syahrin Harahap (2004: 193) explains the student is a predicate as an agent of moral force, agent of change and intellectual force in the life of the nation, state and society, more than other components.

The student is a society that is a candidate of intellectual intellectual who is educated in a certain university, holds a very high predicate in the society, even when in school is considered ready to replace the role of an educator, because through the stage of education that already high can be a person trained according to his area of expertise.

\section{F. Student and Discipline}

Higher education is expected to be a socialization center that is used to study and socialize with students, many people who call college place is a campus where students can take advantage of the library, meet and consult with lecturers outside of college hours, perform sports activities, and where to perform various activities both academic and nonacademic.

Soedijarto (1989: 178) explains that the interaction of the students in the academic environment, and the constant interaction with his lecturer in an atmosphere of intellectual life, challenging academic, and social interaction in nonacademic fields that transcends discipline, is able to personify the value of honesty, the generation of qualified young generation.

In the academic guidance of Faculty of Teacher Training and Education of Tanjungpura University (2015) based on the Decree of Dean of FKIP Untan about the discipline of the lecture, which concerns the students and discipline that is: the students are required to arrive at the lecture before starting and ahead in the class before the lecturer lectures; comply with the requirements of the lecture such as not talking to each other as long as the lecturer gives an explanation; sitting in class in a polite, orderly manner and not making a fuss in the classes that take place lectures; polite in asking questions; trying to have the required literature; not eating and smoking during lectures; and not using the phone during lectures.

Aswandi (2006: 111) suggests a shift in the paradigm of student learning and discipline described as in Table I below:

Table I

Student and Discipline Learning Paradigm Shift

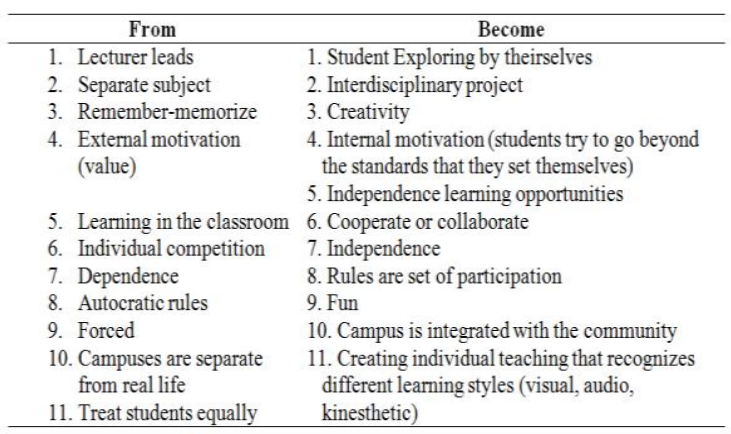

Aswandi (2006: 104) states that in a superior human university has several bits of intelligence, namely intellectual intelligence, emotional intelligence, spiritual intelligence, intelligence facing difficulties, self-esteem intelligence, related intelligence, creative intelligence, discipline 
intelligence, choosing intelligence, acting intelligence, and prophetic intelligence.

From some of the above opinions, that students and discipline really have a very important link because the essence of discipline is the willingness and habits sincerely and understandingly by not taking action contrary to the interests of educational institutions. This is because educational institutions have a role to improve the attitude of discipline, both self-discipline students and the environment in the form of improving the quality of learning process, improving the evaluation system as a means of education, development of living habits following the prevailing provisions and socialization process that can improve the quality of education.

Any institution that implements the discipline system certainly has a good purpose, although the discipline to date is very difficult to accept and apply for the community in social environment and especially for students in the campus environment.

Through the understanding of the shift in learning paradigm and discipline, it is expected to be better understood about the implementation of discipline because students are in an institution that already has rules that must be obeyed and implemented rules that have been applied.

\section{METHODOLOGY}

The method used in this research is descriptive with survey approach. The data collection used a five-Likert scale questionnaire, initially amounting to 45 items of statements but after validity and reliability tests, there were 9 statement items that did not meet the criteria to be excluded from the data analysis. Then the data processed a number of 36 statement items tested with Pearson Product Moment correlation techniques.

\section{IV.RESULTS AND DISCUSSION}

\section{A. Results}

The results of the overall research can be presented in Table II below:

Table II

Classification Percentage of Attitude, Honesty, and Student Responsibility

\begin{tabular}{ccc}
\hline Total Score & Classification & Percentage \\
\hline $28123,6-33480$ & Very Good & $17,2 \%$ \\
\hline $22766,7-28123,5$ & Good & $65,1 \%$ \\
\hline $17409,8-22766,6$ & Fair & $17,7 \%$ \\
\hline $12052,9-17409,7$ & Poor & $0 \%$ \\
\hline $6696-12052,8$ & Very Poor & $0 \%$ \\
\hline
\end{tabular}

In accordance with the data listed in Table II found that students belong to the three classifications that are very good, good and enough. As for the total score grouping of all students is 25301 which means the level of discipline included in the good classification.

From the data Table II above, the difference between the classification level is very good and good can be seen in graph 1 below:

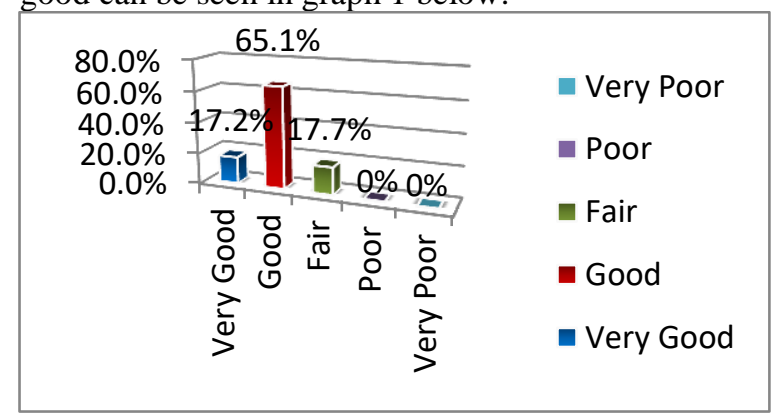

Fig. 1 Weighted Attitudes, Responsibilities, and Student Honesty

Viewed from Table II and Fig.1 above, that the comparison between students with good classification is higher than the classification is very good and enough, the difference of $32.2 \%$. Included in the classification is very good is $17.2 \%$, and included in the classification of both the greater number of $65.1 \%$, while the included in the classification is quite $17.7 \%$. While those included in the classification of less and less once by $0 \%$.

\section{B. Discussion}

Student discipline belongs to four classifications that are very good for 6 people $(3.2 \%)$ indicates that when in the course of lectures have been able to show the attitude to arrive on time, collect tasks on time and follow the lectures seriously; a good classification of 99 people $(53.2 \%)$ indicates that when in the course of lectures students already have a good attitude, come to college on time, collect tasks on time even in lectures are still not really; a classification of 73 persons (39.3\%) indicates that in the course of the lecture already has an adequate attitude; and a classification of fewer than 8 people $(4.3 \%)$ indicates that in the course of lecturing has not reached the criteria. This shows that the attitude of students in the lecture process has a significant difference with still relatively weak. In this case, the student must improve the attitude better to meet the criteria such as coming to college on time, collect the tasks on time and follow the lecture in earnest. Students who belong to the classification is less once that is $0 \%$. This means that no students are included in the classification of this classification, so it can be said that the attitude of students in the lecture process is no longer need to doubt.

The results showed that students are not always perfect, even when running the discipline in the lecture process has its shortcomings and advantages. It can be seen from the attitude, honesty, and responsibility, of course, there are differences, some are active and some are less active, of course, 
discipline is not easy to implement even though it is an obligation in the lecture process that lived.

This study only examines the variables of discipline in the lecturing process of students, therefore this study has the following limitations: this study specifically applies only in physical education program FKIP UNTAN, conditions in the field also determine the smoothness of research activities, therefore, researchers should adjust to schedule of lectures, and there are conditions of students who are less participate in the implementation of charging questionnaires.

\section{CONCLUSION AND SUGGESTION}

\section{A. Conclusion}

Based on the results of research and discussion, it can be concluded that:

Student discipline in lecturing process belongs to three classification that is very good equal to $17,2 \%$, good equal to $65,1 \%$ and enough equal to $17,7 \%$, whereas that included in classification less and less once $0 \%$. For the classification students, both higher than the classification is very good and enough, the difference of $30.2 \%$. This data indicates that the level of student discipline in lecturing process included in the good classification that is equal to $65.1 \%$.

\section{B. Suggestions}

Taking into account the results of the study and the conclusion put forward the following suggestions:

1. Increasing the role of the campus as an institution of attitude-shaping interaction and the socialization of disciplinary values, whether selfdiscipline in lecturing or disciplinary processes in the campus environment.

2. Responsible to maintain a safe, comfortable and orderly atmosphere in the course so that it can comply with the policy and regulations FKIP Untan.

3. It is expected that there will be an effort to conduct further research by taking into account and reducing the limitations that exist in this research.

\section{REFERENCES}

Anonim. (2014). Pengertian danMacam-macam Disiplin.(Online).

(http://www.smkratnawartha.sch.id/index.ph $\mathrm{p} / 2$ info/72pengertian-dan macam- macamdisiplin, dikunjungi 2/4/2014).

Arkaro, S. Jerome. (2005). Pendidikan Berbasis Mutu. Yogyakarta: Pustaka Pelajar.

Armandi, John. Mei (2008). Kontribusi Motivasi Berprestasi dan Disiplin Kerja Terhadap Kinerja Pelatih Jurnal.Iptek Olahraga. Volume 10 (Nomor 2): 97-111. Jakarta: Kemenpora RI.

Aswandi. (2006). Pilar Kebijakan Pendidikan. Pontianak: Muare PR.
Collins, Jim. (2004). Baik Menjadi Hebat. (Penerjemah: Alexander Sindoro). Batam: Kharisma Publishing Group.

Edukasia Press.(2007). Tata Tertib dan Etika Kehidupan Kampus. Pontianak: FKIP UNTAN

(2015). Pedoman Akademik. Pontianak: FKIP UNTAN

Gulo, W. (2010). Metodologi Penelitian. Jakarta: PT.Grasindo.

Hadis, Abdul dan Nurhayati. (2010). Psikologi dalam Pendidikan. Bandung: Alfabeta.

Harahap, Syahrin. (2004). Penegakan Moral Akademik di Dalam dan di Luar Kampus. Jakarta: Rajawali Pers.

http://definisipengertian.com/2012/pengertiandefinisi-mahasiswamenurut-para-ahli/ dikunjungi 9/10/2014

http://reypadji.wordpress.com/2011/03/21/24-kuncisukses/dikunjungi 9/10/2014.

Husdarta, H.J.S. (2011). Psikologi Olahraga. Bandung: Alfabeta.

Khan, Nurdin. (2012). Pengertian Kedisiplinan.(Online).

(http://nurdinkhan.wordpress.com/2012/05/3

0/angket-kedisiplinan-siswa/dikunjungi 12/3/2014).

Nursisto, Johar, Permana (2012). Pengertian Disiplin.(Online). (http://puterirahayuu.com/2012/05/disiplinyeahhh.html, dikunjungi 21/10/2014).

Poerwadarminta, W.J.S. (2003). Kamus Umum Bahasa Indonesia. Jakarta: Balai Pustaka.

Rachman, Maman. ( 1997 ). Manajemen Kelas. Semarang: Proyek Pendidikan Guru Sekolah Dasar Depdikbud Direktorat Jenderal Pendidikan Tinggi.

Riedwan. (2014). Faktor-faktor yang Mempengaruhi Kedisiplinan.(Online).

(http://riedwhan.pun.bz/kedisiplinan-danfaktor-faktor-yang-memp.xhtml, dikunjungi 2/4/2014)

Soedijarto. (1989). Menuju Pendidikan Nasional yang Relevan dan Bermutu. Jakarta: Balai Pustaka. 